\title{
Alternating temperature and accelerated aging in mobilization of reserves during germination of Carica papaya $\mathrm{L}$. seeds $^{1}$
}

\author{
Liana Hilda Golin Mengarda², José Carlos Lopes ${ }^{2 *}$, Rodrigo Sobreira Alexandre ${ }^{3}$, \\ Rafael Fonsêca Zanotti², Pedro Ramon Manhone ${ }^{2}$
}

\begin{abstract}
The aim of this study was to identify the phases of water absorption during germination of Carica papaya seeds and evaluate the influence of alternating temperature and accelerated aging on mobilization of reserves during germination. Weight gain was evaluated, obtaining the imbibition curve. Phase I of germination comprises the period from zero to five hours; phase II, from five to 120 hours; and phase III begins after 144 hours. Seeds were subjected to the germination test under temperatures of $25^{\circ} \mathrm{C}$ and of $20-30{ }^{\circ} \mathrm{C}(16 / 8 \mathrm{~h})$, and before and after accelerated aging $\left(43{ }^{\circ} \mathrm{C} / 72 \mathrm{~h}\right)$. During the germination test, at initial time, after 4,10,120, and 240 hours of soaking, we determined the levels of soluble sugars, starch, lipids, and total proteins. Greater germination was observed under alternating temperature. Under this condition, there is reduction of carbohydrates, lipids, and proteins in phase I, and fluctuations in lipid levels, and an increase in protein levels during phases II and III. Mobilization of lipids in papaya seeds is not influenced by accelerated aging, but the seeds subjected to aging have lower protein content in phase III.
\end{abstract}

Index terms: soaking, papaya, soluble sugars, starch, lipids, proteins.

\section{Alternância de temperatura e envelhecimento acelerado na mobilização de reservas durante a germinação de sementes de Carica papaya L.}

\begin{abstract}
RESUMO - Objetivou-se, neste trabalho, identificar as fases da absorção de água durante a germinação de sementes de Carica papaya e avaliar a influência da alternância de temperatura e do envelhecimento acelerado na mobilização de reservas durante a germinação. Foi avaliado o ganho de peso, obtendo-se a curva de embebição. A fase I da germinação compreende o período entre zero e cinco horas; a fase II, entre cinco e 120 horas; e a fase III se inicia após 144 horas. Sementes foram submetidas ao teste de germinação sob temperaturas de $25^{\circ} \mathrm{C}$ e de $20-30{ }^{\circ} \mathrm{C}(16 / 8 \mathrm{~h})$, e antes e após o envelhecimento acelerado $\left(43{ }^{\circ} \mathrm{C} / 72 \mathrm{~h}\right)$. Durante o teste de germinação, no tempo inicial, após 4, 10, 120 e 240 horas de embebição, foram determinados os teores de açúcares solúveis, amido, lipídeos e proteínas totais. Observou-se maior germinação sob alternância de temperatura. Nesta condição há redução dos carboidratos, lipídeos e proteínas na fase I, flutuações nos teores de lipídeos e aumento nos teores de proteínas durante as fases II e III. A mobilização dos lipídeos em sementes de mamão não sofre influência do envelhecimento acelerado, mas as sementes submetidas ao envelhecimento apresentam menor teor de proteínas na fase III.
\end{abstract}

Temos para indexação: embebição, mamão, açúcares solúveis, amido, lipídeos, proteínas.

\section{Introduction}

Papaya (Carica papaya L.) seeds, just as other orthodox seeds, complete their maturation under a condition of desiccation in which metabolic activity is greatly reduced, requiring reabsorption of water (imbibition) for germination to occur. Germination depends on an ordered sequence of metabolic events that undergo the influence of external stimuli, among which are temperature and aging (Bewley and Black, 1994; Ferreira and

${ }^{1}$ Submitted on 09/03/2014. Accepted for publication on 11/20/2014.

${ }^{2}$ Departamento de Produção Vegetal, Universidade Federal do Espírito Santo, 29500-000, Alegre, ES, Brasil.
Borghetti, 2004; Marcos-Filho, 2005).

Bewley and Black (1994) proposed a triphasic pattern of water absorption during germination, relating the speed of water absorption to digestion of reserves, enzymatic activity, and the formation of macromolecules. The duration of the phases varies a great deal among species. The delimitation of the different phases and understanding of the metabolic events related to each phase carry important information since they may identify more critical stages in the plant life cycle,

${ }^{3}$ Departamento de Ciências Florestais, Universidade Federal do Espírito Santo, 29550-00, Jerônimo Monteiro, ES, Brasil.

*Corresponding author <jcufes@bol.com.br> 
assisting in crop management (Marcos-Filho, 2005). Moreover, identification of the duration of each phase is also relevant for studies on osmoconditioning and for characterization of the mobilization patterns of reserves during germination.

Adequate mobilization of seed reserve compounds is responsible for spurring seedling growth until the seedling acquires photosynthetic efficiency. Mobilization consists of digestion of the reserves and of synthesis of new compounds used for the formation of new protoplasms and cell walls (Nonogakia et al., 2010). Seeds with greater vigor have more reserves of proteins, lipids, and carbohydrates. This provides the seeds with greater storage potential, greater tolerance to stresses, and greater capacity for mobilization of reserves in germination, resulting in seedlings with greater initial performance (Henning et al., 2010; Kim et al., 2011; Zhu and Chen, 2007).

Ideal germination conditions, which involve adequate supply of water, temperature, oxygen, substrate, and light, allow a continual process of mobilization of reserves during germination. Nevertheless, mobilization undergoes the effect of osmotic components (Reis et al., 2012), of salinity (Silva et al., 2008; Dantas et al., 2014), of light and growth regulators (Ren et al., 2007; Zanotti et al., 2014), of accelerated aging (Zhu and Chen, 2007; Menezes et al., 2014), and of storage (Abbade and Takaki, 2014), factors which may accelerate or slow the process, as well as hurt the development of normal seedlings.

Conditions unfavorable to water supply (Reis et al., 2012) and temperature, as well as deterioration processes (MarcosFilho, 2005), may alter or interrupt mobilization of reserves, hurting germination. Thus, the aim of this study was to identify the phases of water absorption during germination of papaya (Carica papaya L.) seeds and evaluate the effect of alternating temperature and accelerated aging on mobilization of reserves during germination.

\section{Material and Methods}

The study was developed at the Seed Analysis Laboratory of the Agrarian Sciences Center of the Universidade Federal do Espírito Santo, Vitoria, ES, Brazil. Hybrid papaya (Carica papaya L.) seeds, JS12 x Waimanalo, were used, and the following evaluations were made:

Water absorption during germination: seeds were used with and without sclerotesta. The removal of the sclerotesta was performed manually, with the aid of a tweezers. The seeds were weighed and distributed in rolls of paper moistened with distilled water and kept in a germination chamber at a temperature of $20-30{ }^{\circ} \mathrm{C}(16 / 8 \mathrm{~h})$. Weight gain was evaluated every 15 minutes in the first hour, every hour for 12 hours, and every 24 hours for 10 days, calculating the moisture content in the seeds. The imbibition curve was determined and, associated with the observation of growth of the primary root, the water absorption phases were delimited (Bewley and Black, 1994).

Constant temperature and alternating temperature: intact seeds were germinated under temperatures of $25^{\circ} \mathrm{C}$ and from 20 $30{ }^{\circ} \mathrm{C}$, and samples were collected for biochemical evaluations.

Accelerated aging: intact seeds were distributed in a single layer over a screen in a gerbox type box with $40 \mathrm{~mL}$ of distilled water in a germination chamber regulated to the temperature of $43{ }^{\circ} \mathrm{C}$ for $72 \mathrm{~h}$. Aged (AS) and non-aged (NAS) seeds were germinated under a temperature of $20-30{ }^{\circ} \mathrm{C}$, with samples being collected for biochemical evaluations.

The physiological quality of the seeds was determined based on the following evaluations:

Percentage of seedlings with radicle protrusion (RP): considering the seeds with radicle protrusion $\geq 0.2 \mathrm{~cm}$ up to 28 days after seeding;

First and second count of seedlings with radicle protrusion (FC and SC): performed at seven and 14 days, respectively, considering the seedlings with radicle protrusion and expressed in percentage. Since they did not exhibit normality and homogeneity, making statistical analysis impossible, the data in regard to $\mathrm{FC}$ were not presented;

Germination speed index (GSI): considering the seedlings with radicle protrusion, calculated according to the formula proposed by Maguire (1962);

Percentage of normal seedlings (NS): calculated in relation to the total of seedlings with radicle protrusion (SP), 28 days after sowing. Under normal seedling conditions, the following evaluations were made:

Length of the shoots (SL) and of the roots $(R L)$ : expressed in cm.seedling ${ }^{-1}$;

Fresh matter (FM) and dry matter (DM): expressed in mg.seedling ${ }^{-1}$. Dry matter was obtained in an air circulation laboratory oven at $70{ }^{\circ} \mathrm{C}$ for $72 \mathrm{~h}$.

For biochemical evaluations, seed samples of $0.1 \mathrm{~g}$ of dry matter were collected at times zero (initial), 4 (phase I), 10 (beginning of phase II), 120 (end of phase II), and 240 hours (phase III) after seeding, with quantification of:

Soluble sugars $(A)$ : extraction was carried out by the methanol, chloroform, and water $(1: 1: 1)$ method, obtaining two liquid phases and one solid phase. The sugars soluble in the solution of the upper portion of the liquid phase were quantified by the anthrone method (Yemn and Willis, 1954);

Lipids (L): lipids were quantified as of the lower portion of the liquid phase of the extraction (Bligh and Dyer, 1959, modified);

Starch (St): the solid phase of the extraction underwent digestion in $3 \% \mathrm{HCl}$ in a water bath and centrifugation, collecting the supernatant, with which the anthrone method 
was carried out;

Total proteins $(P)$ : this was carried out by inference based on the nitrogen level (Galvani and Gaertner, 2006). The results were expressed in percentage $(\% \mathrm{~m} / \mathrm{m})$ of dry matter;

Experimental design and statistical analysis: a completely randomized design was adopted, with four replications of 25 seeds per treatment. Treatments consisted of temperatures, constant $\left(25{ }^{\circ} \mathrm{C}\right)$ and alternating $\left(20-30{ }^{\circ} \mathrm{C}\right)$, in the first experiment; and of non-aged seeds (NAS) and aged seeds (AS), in the second experiment. The experiments were analyzed separately. Analysis of variance was carried out, and the mean values between the treatments were compared by the Tukey test $(\mathrm{p} \leq 5 \%)$. For analysis of soaking times, a $2 \times 5$ split-plot design was adopted, with two treatments [two temperatures $\left(25^{\circ} \mathrm{C}\right.$ and 20-30 ${ }^{\circ} \mathrm{C}$ ) in the first experiment; and two aging conditions (NAS and AS), in the second experiment], and five evaluation times $(0,4,10,120$, and 240 hours), carrying out analysis of regression and adopting models which were significant $(\mathrm{p} \leq$ $5 \%$ ) and of greater order $\left(\mathrm{R}^{2}\right)$ (The R Foundation for Statistical Computing Platform, 2014).

\section{Results and Discussion}

\section{Water absorption during germination:}

The initial moisture content of the seeds with sclerotesta and without sclerotesta was 9.11 and $4.95 \%$, respectively. In the first hour of imbibition, the seeds with sclerotesta reached a moisture content of $62.98 \%$, while the seeds without sclerotesta reached $18.44 \%$ moisture (Figure 1A).

The presence of the sclerotesta affected the imbibition rate of papaya seeds, which was, on average, $43 \%$ greater than in the seeds without sclerotesta. The initial imbibition rate may vary in accordance with the characteristics of the seed coat, the testa, and the pericarp that surrounds the embryo (Ferreira and Borghetti, 2004). In Crotalaria juncea, different moisture absorption rates during imbibition were attributed to the type of coating and to the thickness of the endosperm of different morphotypes of seeds (Pascualides and Planchuelo, 2007).

According to Bewley and Black (1994), imbibition begins with rapid water gain (phase I), a physical process that occurs whether or not the seed is viable or inviable, as long as there is no impermeability of the seed coat. Then, stabilization is observed (phase II) and, after that, the seed returns to gaining moisture with greater speed (phase III). In this study, the absorption pattern was similar among the seeds with and without sclerotesta, with stabilization being observed after five hours of soaking. That way, it was possible to identify the period from zero to five hours as phase I of water absorption during papaya seed germination (Figure 1A).
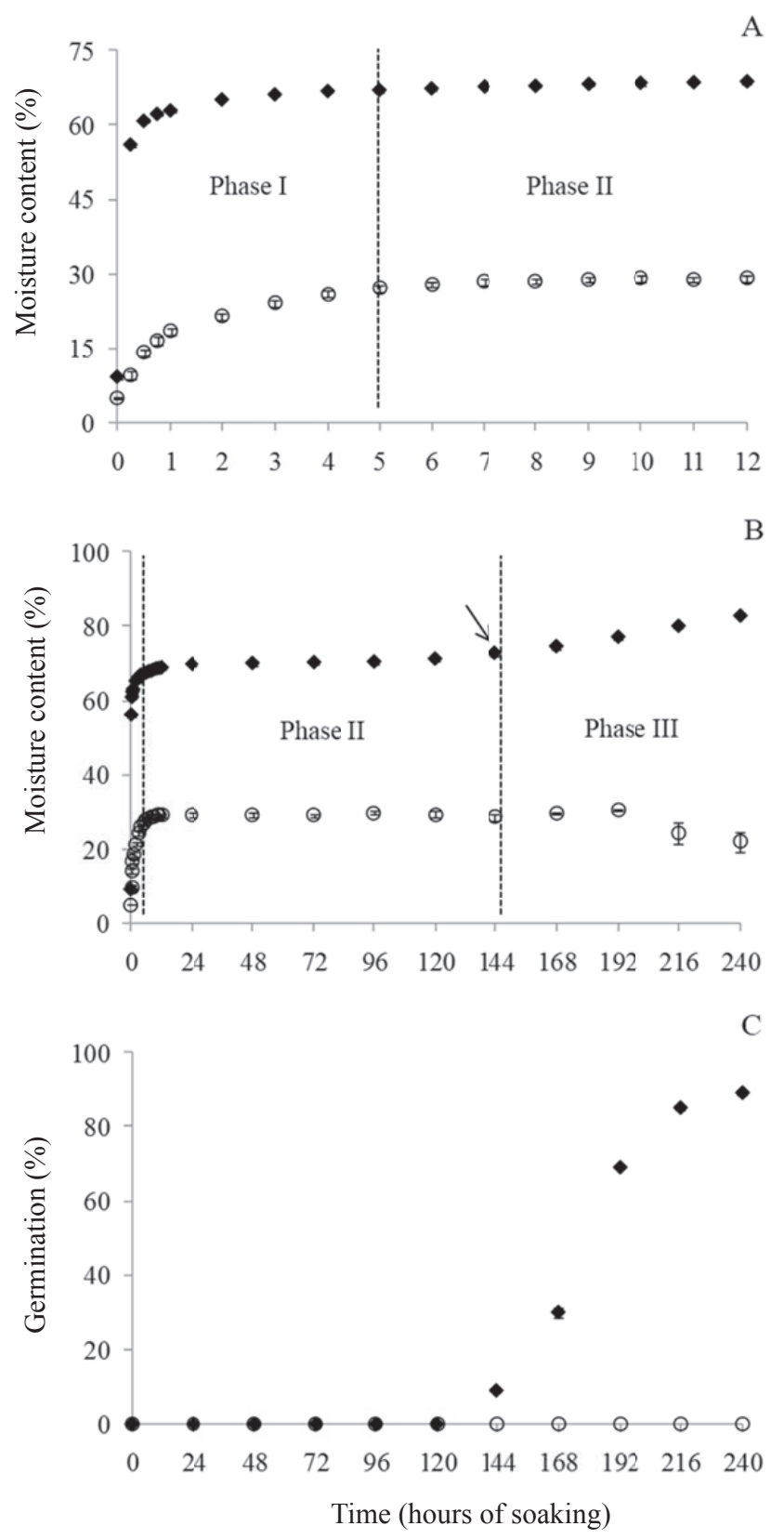

Figure 1. A - moisture content (\%) of papaya seeds with sclerotesta ( $\downarrow)$ and without sclerotesta $(\circ)$ during the first 12 hours of soaking; B - moisture content ( $\%$ ) of seeds with sclerotesta ( $\diamond)$ and without sclerotesta (०) during 240 hours of imbibition. The arrow indicates the beginning of primary root protrusion; $\mathrm{C}$ percentage of seedlings with radicle protrusion from seeds with sclerotesta $(\star)$ and without sclerotesta ( $\circ$ ) during the soaking period. Bars represent the standard error of the mean $(n=4)$.

In the beginning of imbibition of viable seeds, important physiological changes occur. When the seeds reach around 
$20 \%$ moisture, respiration and production of ATP begins; with approximately $40 \%$ moisture, the synthesis of mRNA and repair of DNA, the synthesis of polysomes and of proteins, begins (Bewley and Black, 1994). When the cells achieve full hydration, the moisture content remains constant or increases very slowly, this being a period of preparation for reactivation of metabolism, called phase II (Ferreira and Borghetti, 2004). In this study, the interval from five to 120 hours was observed as phase II (Figures $1 \mathrm{~A}$ and $\mathrm{B})$, in which the moisture content of seeds with sclerotesta ranged from 67.12 to $71.21 \%$. In the seeds with sclerotesta, this variation was from 27.10 to $29.28 \%$ moisture.

Phase II culminates with protrusion of the primary root, which, for many species, occurs with moisture content near $60 \%$. At this point, phase III begins, with a new increase in imbibition, associated with embryo growth (cell division). The passage from phase II to phase III is a point of no return in the germination process; the seed may not undergo stress through water deficiency, which may definitively interrupt germination (Ferreira and Borghetti, 2004; Marcos-Filho, 2005).

For seeds with sclerotesta, the beginning of phase III occurred after 144 hours of soaking, when the seeds reached $73 \%$ moisture, with the beginning of primary root protrusion and a new increase in water absorption being observed. After 240 hours of imbibition, the seeds with sclerotesta exhibited $89 \%$ of seedlings with radicle protrusion (Figures 1B and 1C). Protrusion of the primary root stabilized after 13 days, reaching 93\%. Thus, it was possible to delimit the water absorption phases during germination: phase I occurred in the interval from zero to five hours of soaking; phase II, from five to 120 hours; the transition from phase II to phase II, from 120 to 144 hours; and phase III, as of 144 hours.

The seeds without sclerotesta did not exhibit an increase in moisture content nor root protrusion, but rather deterioration. After 216 hours of imbibition, they exhibited a decrease in weight gain (moisture content) (Figures 1B and C).

Temperature in mobilization of reserves during germination:

Papaya seeds exhibited a greater percentage of seedlings with radicle protrusion under alternating temperature (91\%) as compared to constant temperature (69\%). The temperature of 20-30 ${ }^{\circ} \mathrm{C}$ also led to a greater speed of germination and greater percentage of normal seedlings (Table 1).

In Annona emarginata seeds, a greater percentage of germination was also observed under alternating temperature $\left(20-30{ }^{\circ} \mathrm{C}\right)$ (Costa et al., 2011). Temperature has an effect on water absorption speed and on the speed and uniformity of germination. In addition, temperature is also a determining factor for the biochemical reactions that determine the entire process (Ferreira and Borghetti, 2004; Marcos-Filho, 2005).
Table 1. Physiological quality of papaya seeds subjected to constant temperature $\left(25^{\circ} \mathrm{C}\right)$ and alternating temperature $\left(20-30{ }^{\circ} \mathrm{C}\right)$ : percentage of seedlings with radicle protrusion (RP), second count of seedlings with radicle protrusion (SC), germination speed index (GSI), percentage of normal seedlings (NS), shoot length (SL), root length (RL), fresh matter (FM), and dry matter (DM) of the normal seedlings.

\begin{tabular}{|c|c|c|c|c|}
\hline Temperature & $\mathrm{RP}$ & $\mathrm{SC}$ & GSI & NS \\
\hline $25^{\circ} \mathrm{C}$ & $69 b^{*}$ & $67 \mathrm{~b}$ & $2.13 \mathrm{~b}$ & $66 \mathrm{~b}$ \\
\hline $20-30^{\circ} \mathrm{C}$ & $91 \mathrm{a}$ & $84 \mathrm{a}$ & $2.63 \mathrm{a}$ & $88 \mathrm{a}$ \\
\hline $\mathrm{F}_{\mathrm{cal}}$ & $38.21 * *$ & $20.16 * *$ & $12.44 *$ & $27.92 * *$ \\
\hline \multirow[t]{2}{*}{ CV (\%) } & 6.29 & 7.09 & 8.36 & 7.65 \\
\hline & SL & RL & FM & $\mathrm{DM}$ \\
\hline $25^{\circ} \mathrm{C}$ & $6.75 \mathrm{a}$ & $1.73 \mathrm{~b}$ & $75.10 \mathrm{~b}$ & $3.16 \mathrm{~b}$ \\
\hline $20-30{ }^{\circ} \mathrm{C}$ & $7.26 \mathrm{a}$ & $5.26 \mathrm{a}$ & $96.25 \mathrm{a}$ & $4.70 \mathrm{a}$ \\
\hline $\mathrm{F}_{\mathrm{cal}}$ & $1.33^{\mathrm{ns}}$ & $40.19 * *$ & $24.38 * *$ & $21.67 * *$ \\
\hline CV (\%) & 9.01 & 22.58 & 7.07 & 11.87 \\
\hline
\end{tabular}

*Mean values followed by the same letters (columns) are statistically equal by the Tukey test.", ${ }^{* *}$ Significant at the level of $5 \%$ and $1 \%$, respectively. ${ }^{\text {n }}$ $=$ not significant. $\mathrm{F}_{\mathrm{cal}}=\mathrm{F}$ value calculated obtained by analysis of variance. $\mathrm{CV}(\%)=$ coefficient of variation $(\mathrm{n}=4)$

Concentration of sugars was greater in seeds subjected to constant temperature (Table 2). Under the temperature $20-30{ }^{\circ} \mathrm{C}$ it was observed that after four hours of soaking (phase I), there was a sharp decrease (from 5.93 to $3.63 \%$ ) in the concentration of soluble sugars. That suggests that under alternating temperature, there was mobilization of soluble sugars (Ferreira and Borghetti, 2004).

With alternating temperature $\left(20-30{ }^{\circ} \mathrm{C}\right)$, a lower concentration of starch was observed after 240 hours of soaking (phase III). The lipid concentration exhibited lower mean values after four and 240 hours of soaking (phase I and phase III, respectively). The concentration of total proteins exhibited a lower mean value after four hours of soaking (phase I), and greater mean values in the following evaluations (Table 2).

The mean content of total soluble sugars in the different phases was $5.47 \%$ (Figure $2 \mathrm{~A}$ ). There was no fit to the regression models and, thus, it was not possible to identify the mobilization pattern of these reserves. In Apuleia leiocarpa, it was observed that the mean contents of soluble sugars did not differ significantly during the soaking of the seeds, leading to the conclusion that germination was not dependent on carbohydrates as a source of energy or to create physical structures (Pontes et al., 2002). Nevertheless, interconversion among the different sugars is common, with simultaneous increases in one and decreases in another 
(Ferreira and Borghetti, 2004; Magalhães et al., 2009). Therefore, isolated analysis of the concentrations of total soluble sugars does not allow conclusions to be drawn in regard to their mobilization.

Table 2. Concentrations of soluble sugars, starch, lipids, and total proteins, expressed in percentage ( $\mathrm{m} / \mathrm{m})$ during the germination phases of papaya seeds subjected to constant temperature $\left(25^{\circ} \mathrm{C}\right)$ and alternating temperature $\left(20-30{ }^{\circ} \mathrm{C}\right)$.

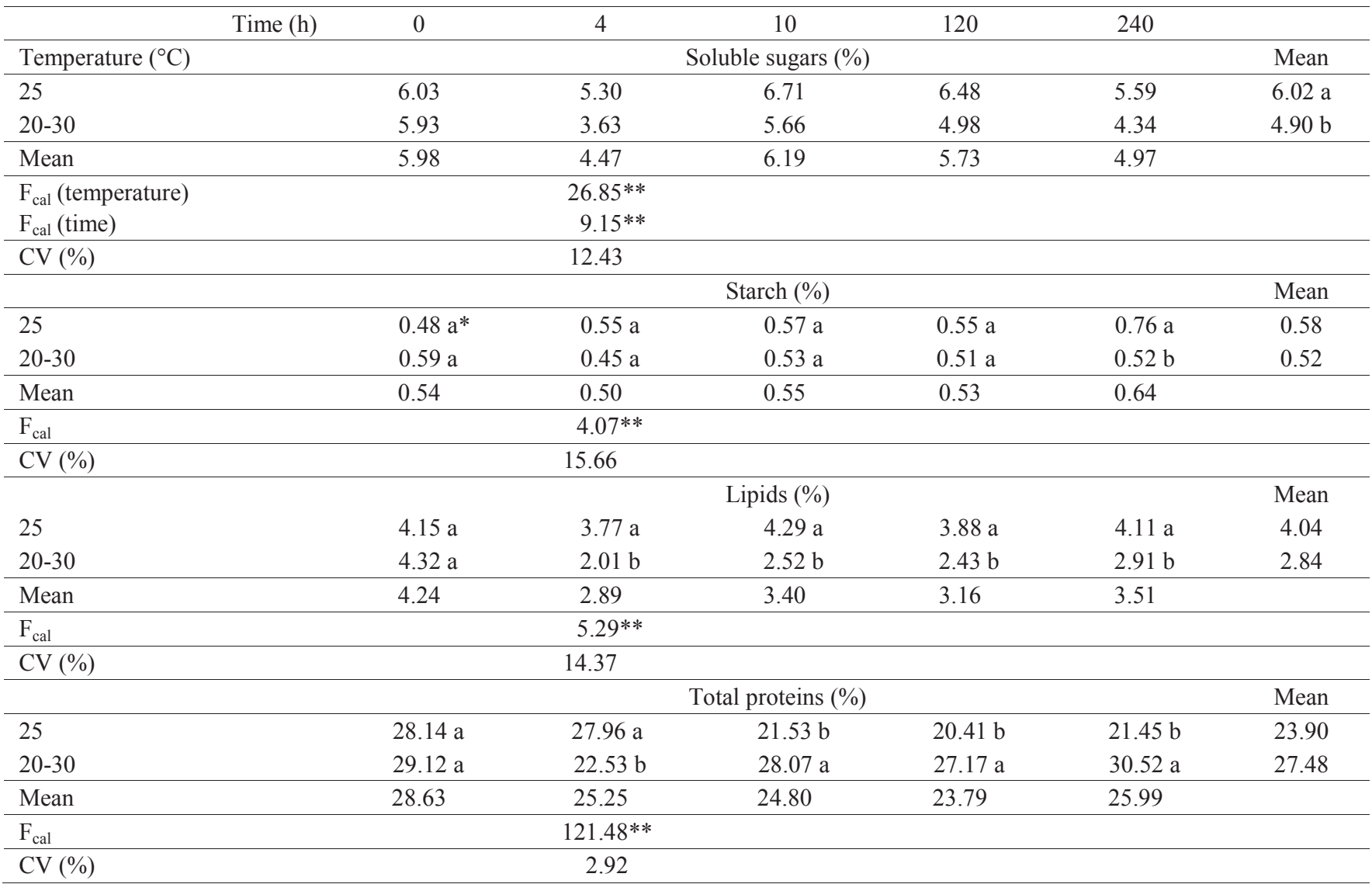

*Mean values followed by the same letters (columns) are statistically equal by the Tukey test.** Significant at the level of $1 \%$. Fcal $=\mathrm{F}$ value calculated obtained by analysis of variance. CV $(\%)=$ coefficient of variation $(n=4)$.

There was a linear increase in the starch contents under constant temperature $\left(25^{\circ} \mathrm{C}\right)$. As for alternating temperature $\left(20-30{ }^{\circ} \mathrm{C}\right)$, the starch content remained constant $(0.52 \%)$ (Figure 2B). Maintenance of a constant starch content may have occurred due to the small quantity present in papaya seeds, which suggests that starch may not play a relevant role as an energy or structural reserve. Furthermore, degradation of starch may be inhibited by the accumulation of its final product (maltose and glucose) since they inhibit beta-amylase activity (Ferreira and Borghetti, 2004).

The concentration of lipids remained constant (4.04\%) at the temperature of $25^{\circ} \mathrm{C}$. As for $20-30{ }^{\circ} \mathrm{C}$, the condition in which a greater percentage of seedlings with radicle protrusion were observed, the initial content showed express reduction, from $4.32 \%$ to $2.01 \%$ after four hours of imbibition (phase I) (Figure $2 \mathrm{C}$ ). At the beginning of germination, the initial substrates used as an energy source are the soluble sugars. Nevertheless, for many seeds, the energy for germination comes from the breakdown of starch and lipids in sucrose (Ferreira and Borghetti, 2004).

After initial reduction in the concentration of lipids, an increase was observed at the beginning of phase II, reduction at the end of phase II, and an increase in phase III, indicating mobilization of these compounds throughout the germination process. As of quantification and evaluation of the mobilization of lipids during germination of Apuleia leiocarpa, it was seen that the energetic and structural needs of the germination are supplied by lipids (Pontes et al., 2002). Corte et al. (2008) suggest the direct involvement of the lipid reserves as energy supply for germination and growth of Caesalpinia peltophoroides seedlings. In papaya seeds, the use of substances like $\mathrm{KNO}_{3}$, effective in increasing germination and in overcoming dormancy, promote greater mobilization of 
lipids (Zanotti et al., 2014). Therefore, it is suggested that lipids exercise an important effect on germination of papaya seeds.

At $25^{\circ} \mathrm{C}$, a fit to the cubic model was observed, with a tendency to reduction in the total protein contents in phase III. Under alternating temperature $\left(20-30^{\circ} \mathrm{C}\right)$, the total protein content fit the quadratic model, with a tendency to increase in the final phases of germination (Figure 2D). While in phase I there is energy consumption and degradation of macromolecules, during phase II, the synthesis of numerous compounds begins. At the end of phase II and in phase
III, amino acids, sucrose, and ATP are translocated to the embryonic axis, which shows an increase in protein contents (Marcos-Filho, 2005; Kim et al., 2011), as observed for the papaya seeds in $20-30{ }^{\circ} \mathrm{C}$.

Thus, under alternating temperature $\left(20-30^{\circ} \mathrm{C}\right)$, it was observed that the initial contents of reserves (sugars, starch, lipids, and proteins) showed reduction at four hours (phase I). In addition, an increase was observed in the protein contents during phases II and III, which may have favored the papaya germination process.
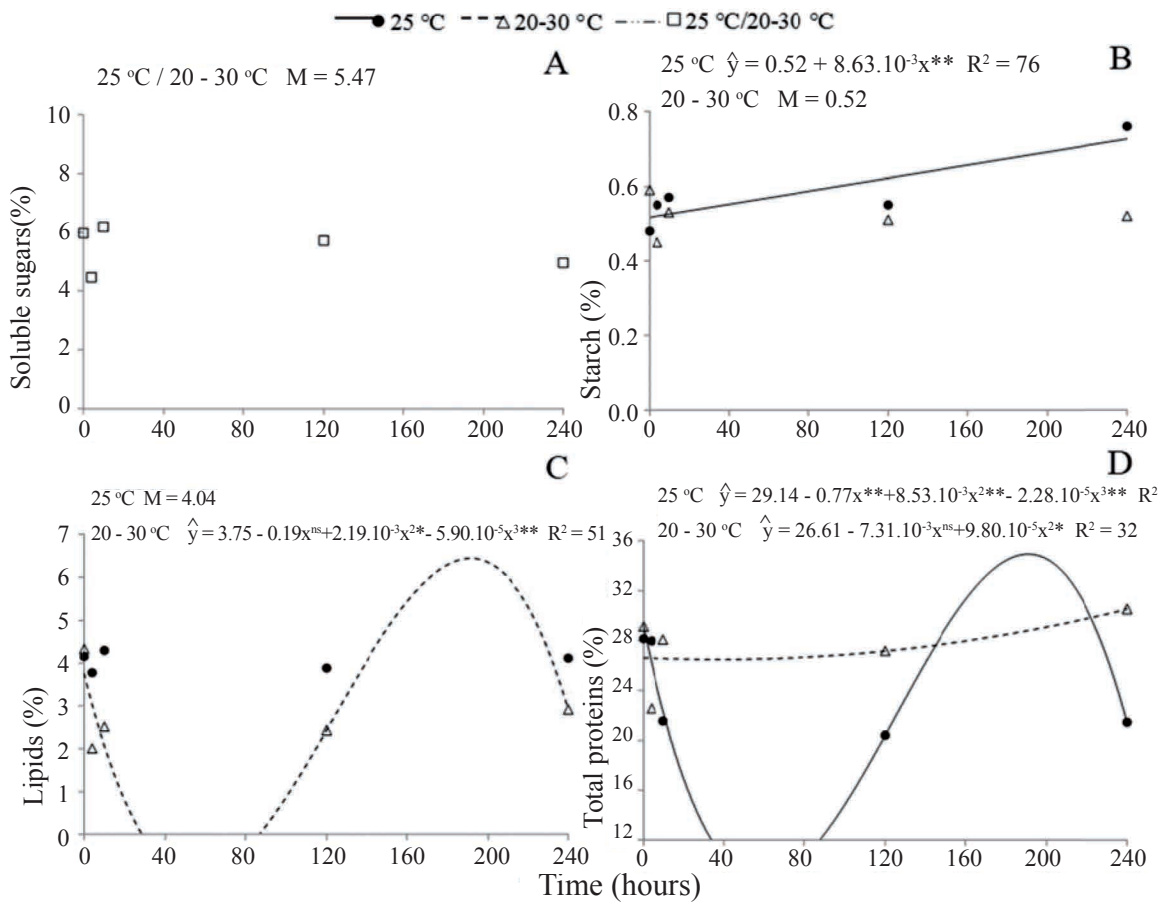

Figure 2. Mobilization of reserves during germination of papaya seeds subjected to constant temperature $\left(25^{\circ} \mathrm{C}\right)$, to alternating temperature $\left(20-30{ }^{\circ} \mathrm{C}\right)$, or to the mean of the two treatments $\left(25^{\circ} \mathrm{C} / 20-30{ }^{\circ} \mathrm{C}\right)$ (interaction not significant): A concentration of soluble sugars; B - concentration of starch; C - concentration of lipids; D - concentration of total proteins. Values expressed in percentage $(\mathrm{m} / \mathrm{m}) . \hat{y}$ - estimated y; $\mathrm{M}-$ mean of the treatment(s). *, ${ }^{* *}$ Significant at the level of $5 \%$ and $1 \%$, respectively; ${ }^{\text {ns }}$ - not significant.

Accelerated aging in mobilization of reserves during germination:

Non-aged seeds (NAS) exhibited greater mean values for second count (SC), germination speed index (GSI), root length (RL), fresh matter (FM), and dry matter (DM) of the seedlings, compared to the seeds subjected to accelerated aging (AS) (Table 3).

The non-aged seeds (NAS) exhibited a lower concentration of soluble sugars after 240 hours of imbibition, and greater concentration of total proteins after 10 and after 240 hours of imbibition. The starch and lipid concentrations, for their part, were not affected by aging (Table 4).

For the non-aged seeds (NAS), a linear reduction was observed in the concentration of sugars, with express reduction after four hours of imbibition, from 5.93 to $3.63 \%$. In the aged seeds (AS), fluctuations were observed in the concentrations of soluble sugars, fitting with the cubic model and with a tendency to increase at the end of germination (Figure 3A). In general, the soluble sugars represent the initial substrates used as an energy source in germination, and a reduction in the concentrations of these compounds is expected (Ferreira and Borghetti, 2004), as observed in the non-aged seeds (NAS). 
Table 3. Physiological quality of non-aged papaya seeds (NAS) subjected to accelerated aging (AS): percentage of seedlings with radicle protrusion (RP), second count of seedlings with radicle protrusion (SC), germination speed index (GSI), percentage of normal seedlings (NS), shoot length (SL), root length (RL), fresh matter (FM), and dry matter (DM) of normal seedlings.

\begin{tabular}{ccccc}
\hline Treatments & RP & SC & GSI & NS \\
\hline NAS & $91 \mathrm{a}^{*}$ & $84 \mathrm{a}$ & $2.13 \mathrm{a}$ & $88 \mathrm{a}$ \\
$\mathrm{AS}$ & $82 \mathrm{a}$ & $67 \mathrm{~b}$ & $1.61 \mathrm{~b}$ & $80 \mathrm{a}$ \\
\hline $\mathrm{F}_{\text {cal }}$ & $4.41^{\mathrm{ns}}$ & $6.24^{*}$ & $37.64^{* *}$ & $3.00^{\mathrm{ns}}$ \\
$\mathrm{CV}(\%)$ & 7.00 & 12.75 & 6.38 & 7.78 \\
\hline & $\mathrm{SL}$ & $\mathrm{RL}$ & $\mathrm{FM}$ & $\mathrm{DM}$ \\
\hline $\mathrm{NAS}$ & $7.26 \mathrm{a}$ & $5.26 \mathrm{a}$ & $4.70 \mathrm{a}$ \\
$\mathrm{AS}$ & $6.25 \mathrm{a}$ & $3.56 \mathrm{~b}$ & $76.15 \mathrm{~b}$ & $4.14 \mathrm{~b}$ \\
\hline $\mathrm{F}_{\text {cal }}$ & $5.52^{\mathrm{ns}}$ & $7.51^{*}$ & $29.72^{* *}$ & $13.48^{*}$ \\
$\mathrm{CV}(\%)$ & 9.00 & 19.89 & 6.05 & 4.90 \\
\hline
\end{tabular}

*Mean values followed by the same letters (columns) are statistically equal by the Tukey test. ${ }^{*},{ }^{* *}$ Significant at the level of $5 \%$ and $1 \%$, respectively. ${ }^{\text {ns }}=$ not significant. $\mathrm{F}_{\text {cal }}=\mathrm{F}$ value calculated obtained by analysis of variance. $\mathrm{CV}(\%)=$ coefficient of variation $(\mathrm{n}=4)$.

Table 4. Concentrations of soluble sugars, starch, lipids, and total proteins, expressed in percentage ( $\mathrm{m} / \mathrm{m})$ during the germination phases of non-aged papaya seeds (NAS) subjected to accelerated aging (AS).

\begin{tabular}{|c|c|c|c|c|c|c|}
\hline Time (h) & 0 & 4 & 10 & 120 & 240 & \\
\hline Treatments & & & Soluble sugars $(\%)$ & & & Mean \\
\hline NAS & $5.93 \mathrm{a}^{*}$ & $3.63 \mathrm{a}$ & $5.66 \mathrm{a}$ & $4.98 \mathrm{a}$ & $4.34 \mathrm{~b}$ & 4.90 \\
\hline AS & $4.80 \mathrm{a}$ & $4.80 \mathrm{a}$ & $5.81 \mathrm{a}$ & $4.20 \mathrm{a}$ & $5.36 \mathrm{a}$ & 4.99 \\
\hline Mean & 5.37 & 4.22 & 5.74 & 4.59 & 4.85 & \\
\hline $\mathrm{F}_{\mathrm{cal}}$ & & $7.37 * *$ & & & & \\
\hline \multirow[t]{2}{*}{ CV (\%) } & & 10.91 & & & & \\
\hline & & & Starch (\%) & & & Mean \\
\hline NAS & 0.59 & 0.45 & 0.53 & 0.51 & 0.52 & $0.52 \mathrm{a}$ \\
\hline AS & 0.60 & 0.56 & 0.55 & 0.46 & 0.52 & $0.54 \mathrm{a}$ \\
\hline Mean & 0.60 & 0.51 & 0.54 & 0.49 & 0.52 & \\
\hline $\mathrm{F}_{\mathrm{cal}}$ (temperature) & & $0.59^{\mathrm{ns}}$ & & & & \\
\hline $\mathrm{F}_{\mathrm{cal}}(\mathrm{time})$ & & $2.27^{\mathrm{ns}}$ & & & & \\
\hline \multirow[t]{2}{*}{ CV (\%) } & & 14.61 & & & & \\
\hline & & & Lipids (\%) & & & Mean \\
\hline NAS & 4.32 & 2.01 & 2.52 & 2.43 & 2.91 & $2.84 \mathrm{a}$ \\
\hline AS & 3.67 & 2.93 & 2.51 & 2.48 & 3.65 & $3.04 \mathrm{a}$ \\
\hline Mean & 4.00 & 2.47 & 2.52 & 2.46 & 3.28 & \\
\hline $\mathrm{F}_{\mathrm{cal}}$ (temperature) & & $1.43^{\mathrm{ns}}$ & & & & \\
\hline $\mathrm{F}_{\mathrm{cal}}($ time $)$ & & $12.44 * *$ & & & & \\
\hline CV (\%) & & 18.65 & & & & \\
\hline Treatments & & & Total proteins $(\%)$ & & & \\
\hline NAS & $29.12 \mathrm{a}$ & $22.53 \mathrm{~b}$ & $28.07 \mathrm{a}$ & $27.17 \mathrm{~b}$ & $30.52 \mathrm{a}$ & 27.48 \\
\hline AS & $28.28 \mathrm{a}$ & $28.68 \mathrm{a}$ & $27.13 \mathrm{~b}$ & $29.79 \mathrm{a}$ & $29.31 \mathrm{~b}$ & 28.64 \\
\hline Mean & 28.70 & 25.61 & 27.60 & 28.48 & 29.92 & \\
\hline $\mathrm{F}_{\mathrm{cal}}$ & & $55.49 * *$ & & & & \\
\hline CV $(\%)$ & & 2.17 & 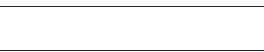 & & & \\
\hline
\end{tabular}




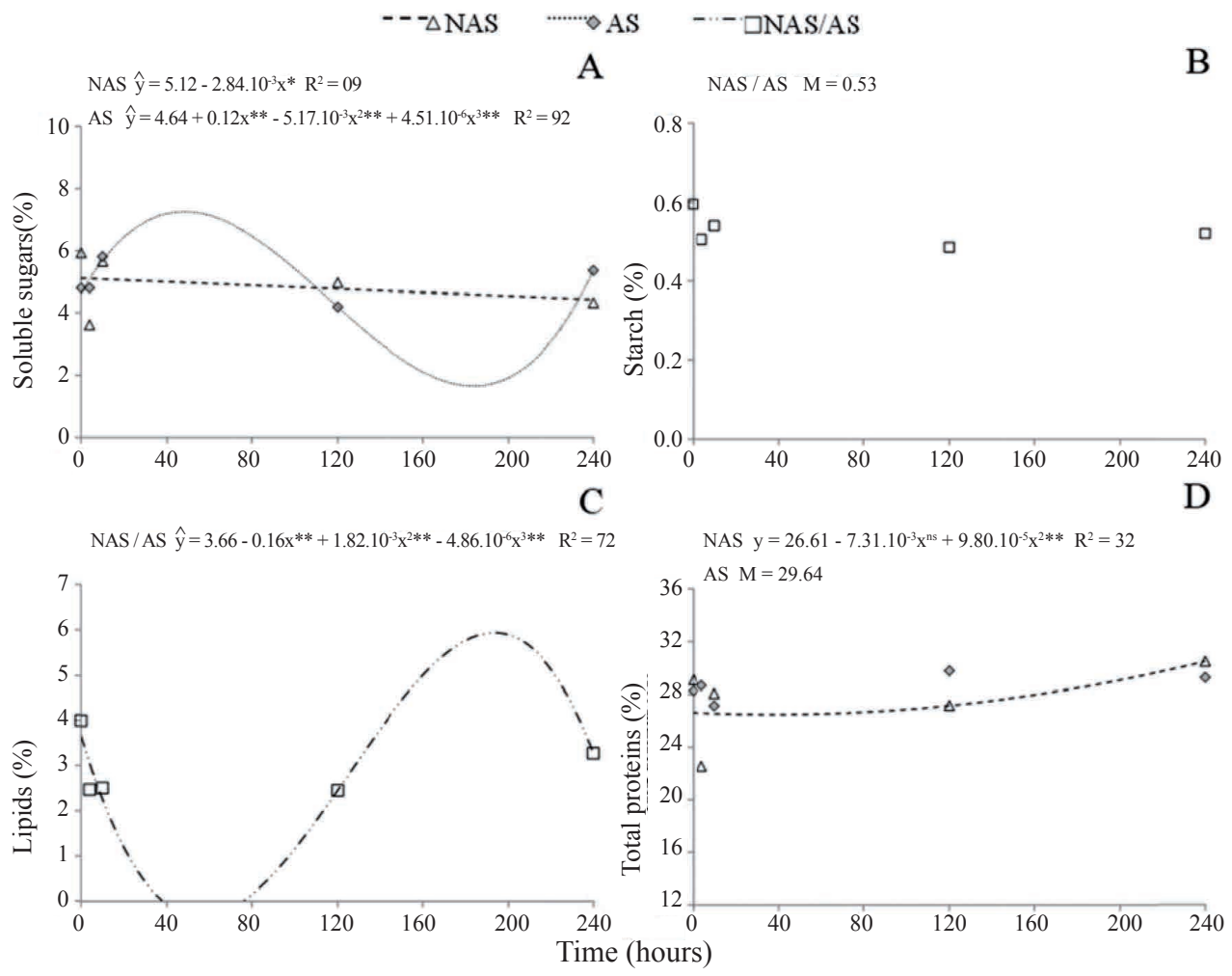

Figure 3. Mobilization of reserves during germination of non-aged papaya seeds (NAS), seeds subjected to accelerated aging (AS), or to the mean of the two treatments (NAS/AS) (interaction not significant): A - concentration of soluble sugars; B - concentration of starch; C - concentration of lipids; D - concentration of total proteins. Values expressed in percentage $(\mathrm{m} / \mathrm{m}) \cdot \hat{y}$ - estimated y; $\mathrm{M}$ - mean of the treatment(s). *, ${ }^{* *}$ Significant at the level of $5 \%$ and $1 \%$, respectively; ${ }^{\text {ns }}$ - not significant.

The starch was not affected by the soaking times, remaining constant throughout the germination phases $(0.53 \%)$ (Figure 3B).

The concentrations of lipids showed reduction after four and 10 hours (phase I and beginning of phase II), an increase after 120 hours (end of phase II), and a tendency to reduction after 240 hours of soaking (phase III), fitting with the cubic model of regression (Figure 3C). Thus, apart from AS, the mobilization of lipids showed behavior similar to that observed for seeds subjected to alternating temperature (Figure 2C), which showed high germination (Table 2). Therefore, the mobilization of lipids was not affected by accelerated aging and, although the seeds subjected to AS showed reduction in vigor (lower germination speed and reduction in seedling development), they did not show reduction in the percentages of seedlings with radicle protrusion and of normal seedlings.

The concentration of total proteins in the non-aged seeds (NAS) showed a tendency to increase during phases II and III, fitting the quadratic model. The aged seeds (AS) did not fit the models of regression (Figure 3D). In the seed deterioration process, there may be a decrease in the concentration and synthesis of proteins, as well as denaturation brought about by high temperatures (Bewley and Black, 1994; Marcos-Filho, 2005; Kim et al., 2011). As a consequence, the number of cells in division and the mitoctic index may be affected, as observed in Triticum aestivum seeds (Menezes et al., 2014).

In Tabebuia roseoalba seeds, a reduction in physiological quality of the seeds was observed, brought about by storage, with reduction in protein levels (Abbade and Takaki, 2014). Accelerated aging provides a favorable condition to seed deterioration, similar to storage. Thus, the low concentration of proteins observed in the aged seeds in phase III suggests that the reduction in the vigor of seeds subjected to aging may be related to the compromising of mobilization of proteins. 


\section{Conclusions}

Phase I of water absorption during the germination of papaya (Carica papaya L.) seeds includes the period from zero to five hours of soaking; phase II, from five to 120 hours; and phase III begins after 144 hours of soaking.

Papaya seeds show greater germination under alternating temperature, with reduction in the concentrations of sugars, starch, lipids, and proteins during phase I of germination, mobilization of lipids, and increase in the concentrations of proteins during phases II and III.

The mobilization of lipids in papaya seeds is not affected by accelerated aging. Nevertheless, the seeds subjected to aging have a lower concentration of proteins in phase III, which may be related to reduction in vigor.

\section{Acknowledgments}

Thanks to Caliman Agrícola S/A for supplying plant material. To the CAPES and to the CNPq for granting scholarships for graduate studies and for research productivity, respectively.

\section{References}

ABBADE, L.C.; TAKAKI, M. Biochemical and physiological changes of Tabebuia roseoalba (Ridl.) Sandwith (Bignoniaceae) seeds under storage. Journal of Seed Science, v.36, n.1, p.100-107, 2014. http://www.scielo.br/ $\mathrm{pdf} / \mathrm{js} / \mathrm{v} 36 \mathrm{n} 1 / \mathrm{a} 13 \mathrm{v} 36 \mathrm{n} 1 . \mathrm{pdf}$

BEWLEY, J.D.; BLACK, M. Seeds: physiology of development and germination.New York: Plenum Press, 1994. 445p.

BLIGH, E.G.; DYER, W.J. A rapid method of total lipid extraction and purification. Canadian Journal Biochemistry and Physiology, v.37, n.8, p. 911-917, 1959

CORTE, V.B.; BORGES, E.E.L.; VENTRELLA, M.C.; LEITE, I.T.A.; BRAGA, A.J.T. Histochemical aspects of reserves mobilization of Caesalpinia peltophoroides (Leguminosae) seeds during germination and seedlings early growth. Revista Árvore, v.32, n.4, p.641-650, 2008. http:// www.scielo.br/pdf/rarv/v32n4/a05v32n4.pdf

COSTA, P.N.; BUENO, S.S.C.; FERREIRA, G. Fases da germinação de sementes de Annona emarginata (Schltdl.) H. Rainer em diferentes temperaturas. Revista Brasileira de Fruticultura, v.33, n.1, p.253-260, 2011. http://www.scielo.br/pdf/rbf/v33n1/aop01011.pdf

DANTAS, B.F.; RIBEIRO, R.C.; MATIAS, J.R.; ARAÚJO, G.G.L. Germinative metabolism of Caatinga forest species in biosaline agriculture. Journal of Seed Science, v.36, n.2, p.194-203, 2014. www.scielo.br/pdf/jss/ v36n2/v36n2a08.pdf

FERREIRA, A.G.; BORGHETTI, F. Germinação: do básico ao aplicado. Porto Alegre: Artmed, 2004, 323p.

GALVANI, F.; GAERTNER, E. Adequação da metodologia Kjeldahl para determinação de nitrogênio total e proteína bruta (Circular Técnica 63). Corumbá: Embrapa Pantanal, 2006. 9p.
HENNING, F.A.; MERTZ, L.M.; JACOB JUNIOR, E.A.; MACHADO, R.D.; FISS, G.; ZIMMER, P.D. Composição química e mobilização de reservas em sementes de soja de alto e baixo vigor. Bragantia, v.69, n.3, p.727-734, 2010. http://www.scielo.br/pdf/brag/v69n3/26.pdf

KIM, H.T.; CHOI, U.; RYU, H.S.; LEE, S.J.; KWON, O. Mobilization of storage proteins in soybean seed (Glycine max L.) during germination and seedling growth. Biochimica et Biophysica Acta, v.1814, p.1178-1187, 2011. http://www.sciencedirect.com/science/article/pii/S1570963911001282

MAGALHÃES, S.R.; BORGES, E.E.L.; BERGER, A.P.A. Alterações nas atividades das enzimas alfa-galactosidase e poligalacturonase e nas reservas de carboidratos de sementes de Schizolobium parahyba (Vell.) Blake (Guapuruvú) durante a germinação. Revista Brasileira de Sementes, v.31, n.2, p.253-261, 2009. http://www.scielo.br/pdf/rbs/v31n2/v31n2a30.pdf

MAGUIRE, J.D. Speeds of germination-aid selection and evaluation for seedling emergence and vigor. Crop Science, v.2, p.176-177, 1962.

MARCOS-FILHO, J. Fisiologia de sementes de plantas cultivadas. Piracicaba: FEALQ, 2005. 495p.

MENEZES, V.O.; LOPES, S.J.; TEDESCO, S.B.; HENNING, F.A.; ZEN, H.D.; MERTZ, L.M. Cytogenetic analysis of wheat seeds submitted to artificial aging stress. Journal of Seed Science, v.36, n.1, p.71-78, 2014. http://www.scielo.br/pdf/jss/v36n1/a09v36n1.pdf

NONOGAKIA, H.; BASSELB, G.W.; BEWLEY, J.D. Germination - Stil a mystery. Plant Science, v.179, p.574-581, 2010. http://www.sciencedirect. com/science/article/pii/S016894521000040

PASCUALIDES, A.L.; PLANCHUELO, A.M. Seed morphology and imbibition pattern of Crotalaria juncea L. (Fabaceae). Seed Science \& Technology, v.35, p.760-764, 2007. http://www.ingentaconnect.com/content/ ista/sst/2007/00000035/00000003/art00024

PONTES, C.A.; BORGES, E.E.L.; BORGES, R.C.G.; SOARES, C.P.B. Mobilização de reservas em sementes de Apuleia leiocarpa (Vogel) J.F. Macbr. (Garapa) durante a embebição. Revista Árvore, v.26, n.5, p. 593-601, 2002. http://www.scielo.br/pdf/rarv/v26n5/a10v26n5.pdf

REIS, R.C.R.; DANTAS, B.F.; PELACANI, C.R. Mobilization of reserves and germination of seeds of Erythrina velutina Willd. (LeguminosaePapilionoideae) under different osmotic potentials. Revista Brasileira de Sementes, v.34, n.4, p.580-588, 2012. http://www.scielo.br/pdf/rbs/ v34n4/08.pdf

REN，C.; BILYEU， K.D.; ROBERTS， C.A.; BEUSELINCK， P.R Factors regulating the mobilization of storage reserves in soybean cotyledons during post-germinative growth. Seed Science \& Technology, v.35, p.303-317, 2007. http://www.ingentaconnect.com/content/ista/ sst/2007/00000035/00000002/art00006

SILVA, R.N.; DUARTE, G.L.; LOPES, N.F.; MORAES, D.M.; PEREIRA, A.L.A. Composição química de sementes de trigo (Triticum aestivum L.) submetidas a estresse salino na germinação. Revista Brasileira de Sementes, v.30, n.1, p.215-220, 2008. http://www.scielo.br/pdf/rbs/v30n1/a27v30n1.pdf

THE R FOUNDATION FOR STATISTICAL COMPUTING PLATAFORM. $R$. A language and environment for statistical computing. Version 3.1.1 Vienna: R Foundation for Statistical Computing, 2014. http://www.rproject.org/

YEMN, E.W.; WILLIS, A.J. The estimation of carbohydrate in plant extracts by anthrone. The Biochemical Journal, v.57, p.508-514, 1954. http://www. ncbi.nlm.nih.gov/pmc/articles/PMC1269789/pdf/biochemj01083-0159.pdf 
ZANOTTI, R.F.; DIAS, D.C.F.S.; BARROS, R.S.; DAMATTA, F.M.; OLIVEIRA, G.L. Germination and biochemical changes in 'Formosa' papaya seeds treated with plant hormones. Acta Scientiarum Agronomy, v.36, n.4, p.435-442, 2014. http://periodicos.uem.br/ojs/index.php/ActaSciAgron/ article/view/18057/pdf_38
ZHU, C.; CHEN, J. Changes in soluble sugar and antioxidant enzymes in peanut seeds during ultra dry storage and after accelerated aging. Seed Science \& Technology, v.35, n.2, p. 387-401, 2007. http://www.ingentaconnect.com/ content/ista/sst/2007/00000035/00000002/art00014 